\title{
MANUFACTURING OF AMBER PARTICLES SUITABLE FOR COMPOSITE FIBRE MELT SPINNING
}

\author{
Inga L̦ašenko ${ }^{1 \#, ~ S e r g e j s ~ G a i d u k o v s ~}{ }^{2}$, and Jūlija Rombovska ${ }^{3}$ \\ ${ }^{1}$ Institute of Biomedical Engineering and Nanotechnologies, Rīga Technical University, Pulka iela 3/3, Rīga, LV-1007, LATVIA; \\ inga.lasenko@inbox.lv \\ 2 Institute of Polymer Materials, Rīga Technical University, Āzenes iela 14/24, LV-1048, Rīga, LATVIA \\ 3 Faculty of Medicine, Rīga Stradinš University, Dzirciema iela 16, Rĩga, LV-1007, LATVIA \\ \# Corresponding author
}

Communicated by Ivars Knēts

\begin{abstract}
Polyamide fibre containing amber particles was fabricated. The amber particles were obtained by grinding technology using planetary ball-mills. Scanning electron microscopy and granulometry testing were used to characterise the structure and the size of prepared amber particles. Fourier transform infrared spectroscopy was used to analyse the chemical structure of the amber particles. The amber particles were characterised with average size up to $3 \mu \mathrm{m}$. The chemical composition of amber before and after the grinding remained unchanged. The amber particles were melt-extruded using polyamide 6 as the matrix. Melt spinning processing was used to fabricate polyamide-amber filaments. Pre-oriented yarns and fully drawn yarns were obtained after hotdrawing experiments. Reported experimental findings of amber composite fibre could be important for textile applications.
\end{abstract}

Key words: amber, polyamide, fibre, extrusion processing, melt spinning.

\section{INTRODUCTION}

Methods are being developed for manufacture of polymer composites using organic and inorganic functional mineral powders, which are integrated in polymer matrix (Ibanes et al., 2004). In this paper, we present a method for the preparation of amber particles suitable for melt extrusion and spin drawing.

Amber is considered to have bioactivity and biocompatibility (Hazelwood, 2001; Chen et al., 2003; Thrall, 2004). The active compound of amber is succinic acid. Succinic acid plays a significant role in metabolism (Krebs cycle) and occurs in mitochondria. In medicine, succinic acid and its derivatives are used as anxiolytic, antispasmer, antiphlegm, antiphlogistic, and antitumour agents (Agarwal et al., 2007). Succinic acid is a strong electron donor. It participates in processes associated with energy production (Mie et al., 2008). It can provide free electrons in order to maintain energetic potential in cells with aerobic respiration. Amber also has a biostimulating effect on new cell formation in skin, simultaneous tissue and skin derivatives, which stimulates skin and hair restoration; it does not cause skin irritation and organism sensitisation (Archambault et al., 2008).

Study of cotton pads impregnated with a suspension containing amber particles showed lack of skin irritation and organism sensitisation (Sprudza et al., 2009; Synoradzki et al., 2012). Textile fabric impregnated with technologically processed amber, investigated in vivo, did not cause irritation, caustic effect and had a biostimulating effect on the creation of the new cell in skin, subcutaneous tissue and skin derivatives, and promoted skin renewal.

Fabrics containing the amber composite fibre can be used as a medical textile for external applications, when skin changes occur, including for skin condition improvement for diabetics and as preventive compression products. Studies by AITEX (Spanish Textile Technology Institute, International Certification Organisation) (according to Oeko-Tex Standart 100) confirm that amber composite fibre meets the human-ecological requirements of the standard presently established for infant fabrics (product class I, Certificate 2013LK0012). The Oeko-Tex Standart 100 concluded positive medical impacts of amber composite fibres concerning the skin: biocompatibility, does not cause skin irritation and organism sensitisation. Amber composite fibres also have been assessed with in vitro cytotoxicity tests according to UNE-EN ISO 10993-5:2009; a satisfactory certificate MADE FOR HEALTH® Nr 2014TM0281 was issued by AITEX.

Melt extrusion and spinning of PA6-amber fibre has been reported (Lašenko, 2014). Fully drawn yarns (FDY) and 
pre-oriented yarns (POY) melt spinning processes with PA6-amber fibre have been performed (Schäfer 1999). The use of the melt spinning process and conditions (temperature, velocity, denier) for PA6-amber fibre is described in the present investigation.

\section{MATERIALS AND METHODS}

Raw materials. Amber pellets ( $\sim 5 \mathrm{~mm}, \mathrm{CAS}$ : 9000-02-6, EC: 232-520-0) used in this study were obtained from Kaliningrad region of Russian Federation. RADIPOL S100$004 \AA$ is polyamide 6 (PA6), which has a low molecular substance content $(0.9 \%)$ and melting temperature of $220{ }^{\circ} \mathrm{C}$.

Preparation of amber particles. The first step of amber particle preparation was their purification by flotation. Flotation was based on the difference in density of amber and impurities, whereby amber was separated from crystalline minerals (quartz) and amorphous impurities (silica). The flotation device consisted of two flotation chambers equipped with a foam picker device and compressed air supply device. The flotation camera was fed with fresh deionised water (density $1.00 \mathrm{~g} / \mathrm{cm}^{3}$ ) at temperature $20{ }^{\circ} \mathrm{C}$. Ash particles were raised to the water surface by supply of compressed air and collected. Amber has a density of 1.08 $\mathrm{g} / \mathrm{cm}^{3}$, and therefore remained at the bottom of the chamber. The second flotation chamber was fed with $\mathrm{NaCl}$ salt-water solution (density $1.02 \mathrm{~g} / \mathrm{cm}^{3}, \mathrm{NaCl} 200 \mathrm{~g} / \mathrm{l}$ ) at temperature $30{ }^{\circ} \mathrm{C}$. In this chamber amber pellets floated on the surface of water, while quartz, mica, and felspar, which had higher density, remained on the bottom. Amber pellets were collected with the foam picker, placed in an oven to dry for 10 $\min$ at $45{ }^{\circ} \mathrm{C}$.

After that amber pellets were pre-ground (1) with a planetary ball-mill Pulverisette 5 Fritsch (Germany). $45 \mathrm{~g}$ of amber was ground in a $250 \mathrm{ml}$ agate bowl with $15 \times 20 \mathrm{~mm}$ $\mathrm{SiO}_{2}$ balls at $400 \mathrm{rpm}$ for $10 \mathrm{~min}$. The processed amber-water slurry was used in the main grinding steps, which was performed on mill devices 01-HD Attritor, Union Process and 01-HDDM Attritor, Union Process (USA). The second grinding step (2) was performed with 3 or $5 \mathrm{~mm}$ $\mathrm{YTZ}^{\circledR}$ media. The third grinding step (3) was performed with $0.4-0.6 \mathrm{~mm} \mathrm{YTZ}^{\circledR}$ media. Processing rates were 600 and $1900 \mathrm{rpm}$, correspondingly. Tank volume was $1400 \mathrm{ml}$. Slurry temperature during the process was $16^{\circ} \mathrm{C}$. The tank was continuously cooled with circulating water. Every 30 or $60 \mathrm{~min}$ the slurry was sampled for granulometric testing. After the grinding, amber was dried in the oven for $48 \mathrm{~h}$ at $45{ }^{\circ} \mathrm{C}$, resulting in dry amber powder (see Fig. 1b). The obtained amber powder was stored in a tightly closed container and desiccator without access to moisture and sunlight.

Methods for particle analysis. A twin-screw extruder Berstorff ZE25-38D (Germany) was used for polyamide and amber particle melt compounding. The machine settings were the following: screw speed $300 \mathrm{rpm}$, barrel temperature $240{ }^{\circ} \mathrm{C}$, melt temperature $265{ }^{\circ} \mathrm{C}$, mass flow 10 $\mathrm{kg} / \mathrm{h}$.
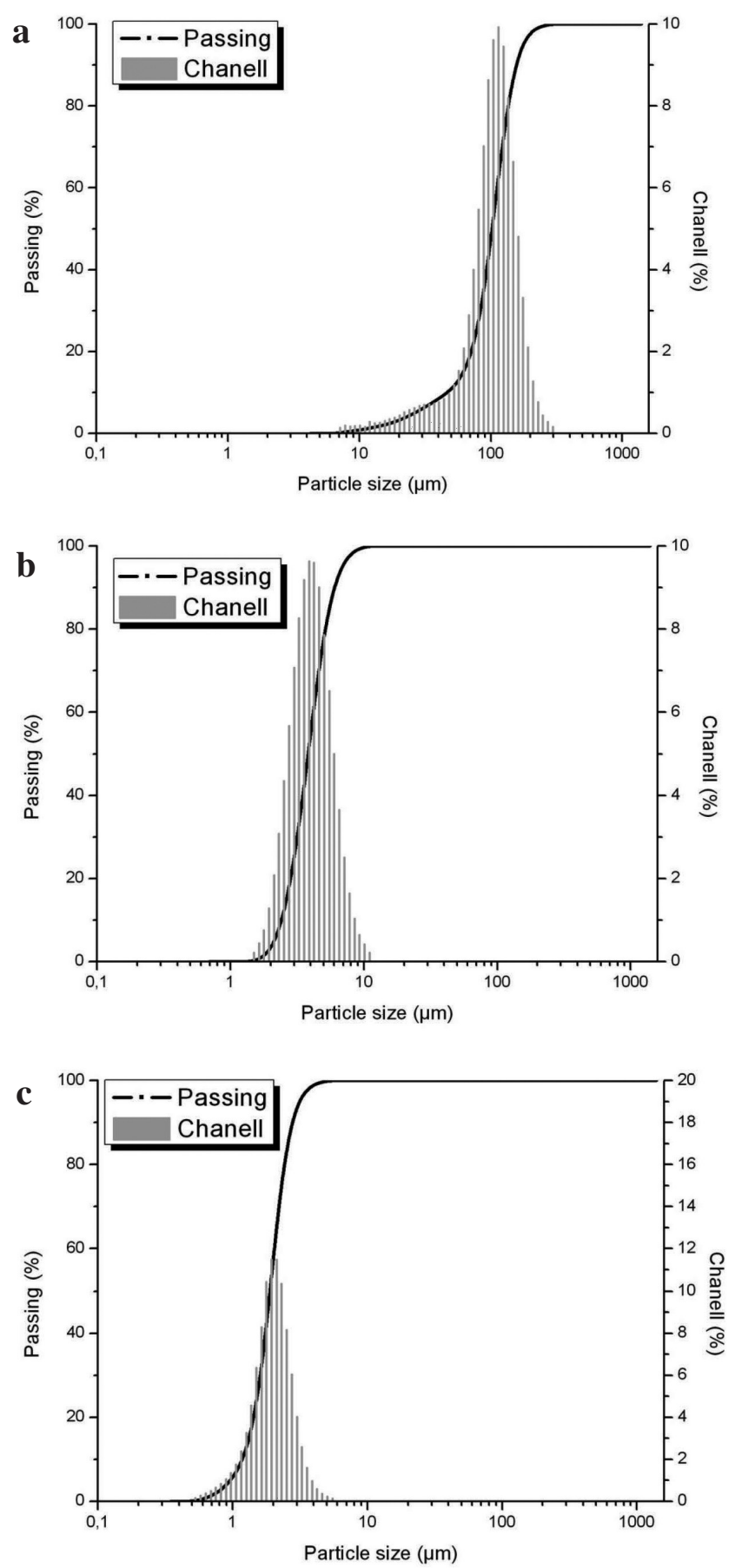

Fig. 1. Granulometric curves and volume-size histograms of amber particles; (a) after the first grinding stage; (b) after the second grinding stage; (c) after the third grinding stage.

Fibre melt spinning was performed with a laboratory extruder VarioFil (Oerlikon Barmag, Germany). Melt drawing trial conditions are summarised in Table 1.

A Particle Size Analyzer 90 Plus with ZetaPALS of Brookhaven Instruments Corporation was used for granulometric testing. Ten measurements were performed; average error was $10 \%$.

The structure and shape of amber particles and fibres was observed under a scanning electron microscope (SEM) 
Table 1

POY AND FDY CONFIGURATION PROCESS

\begin{tabular}{ll}
\hline POY Configuration & Configuration for FDY \\
- speed $2000-4500 \mathrm{~m} / \mathrm{min}$, & - speed $2000-4500 \mathrm{~m} / \mathrm{min}$, \\
- titre up to $300 \mathrm{den}(\mathrm{final})$, & - titre up to $1.200 \mathrm{den}$, \\
- filament count $(0.5) 1.0-4.0 \mathrm{dpf}$ & - filament count $1.0-10.0 \mathrm{dpf}$, \\
$\quad$ (final), & - tenacity $3.5-6 \mathrm{~g} / \mathrm{den}$, \\
- elongation $60-250 \%$, & - yarn uniformity (USTER) $<1 \%$.
\end{tabular}

- tenacity $1.7-3.4 \mathrm{~g} / \mathrm{den}$

- yarn uniformity (USTER) $<1 \%$.

TESCAN MiralLMU Field-Emission-Gun. The accelerating voltage was $15 \mathrm{kV}$.

Fourier transform infrared spectroscopy (FTIR) is a common method for determination of amber chemical composition (Beck et al., 1964; Pakutinskiene et al., 2007). FTIR spectra were recorded on a Varian Scimitar 800 FTIR spectrometer. The measurement range was $400-4000 \mathrm{~cm}^{-1}$ with accuracy $\pm 4 \mathrm{~cm}^{-1}$ using $\mathrm{KBr}$ as a beam splitter. Samples were prepared by mixing amber particles with dried, anhydrous $\mathrm{KBr}$ (Merck, Germany) and compressed for tablets. 15 scans were performed and the mean spectra curve was obtained.

A moisture analyser KERN MRS 120-3 was used to measure moisture of the amber pellets and powder.

\section{RESULTS}

Figure 1 shows granulometric curves and volume-size histograms of amber particles for different grinding stages. Figure 2 shows how particle size depends on the time of grinding. Figure 3 shows SEM micrographs of the processed amber particles. Figure 4 shows FTIR spectra of the initial amber (a) and the processed amber particles after grinding (b).

The technological process of PA6-amber fibre included the following steps: the melt extrusion of the concentrate of PA6-amber $5 \mathrm{wt} \%$; the secondary melt extrusion of PA6-amber $1 \mathrm{wt} \%$ composite using the obtained concentrate and neat PA6 from the first step; melt spinning of PA6-amber 1 wt\% fibre; and PA6-amber composite fibre lubrication and stretching. The processing parameters for these FDY spinning trials (0)-(3) are shown in Table 3.

\section{DISCUSSION}

The particle size decreased during grinding: 10-500 $\mu \mathrm{m}$ after grinding stage (1), 1-10 $\mu \mathrm{m}$ after grinding stage (2), and $0.5-8 \mu \mathrm{m}$ after grinding stage (3).

During the grinding stage (2), after $240 \mathrm{~min}$. the particle mean size decreased from $180 \mu \mathrm{m}(95 \%)$ to $10 \mu \mathrm{m}(95 \%)$. After stage (3), the particle size decreased to $3 \mu \mathrm{m}$ (95\%). The amber particle size started to slightly increase during longer grinding times, due to aggregation of small particles. The optimal grinding time was $30 \mathrm{~min}$.
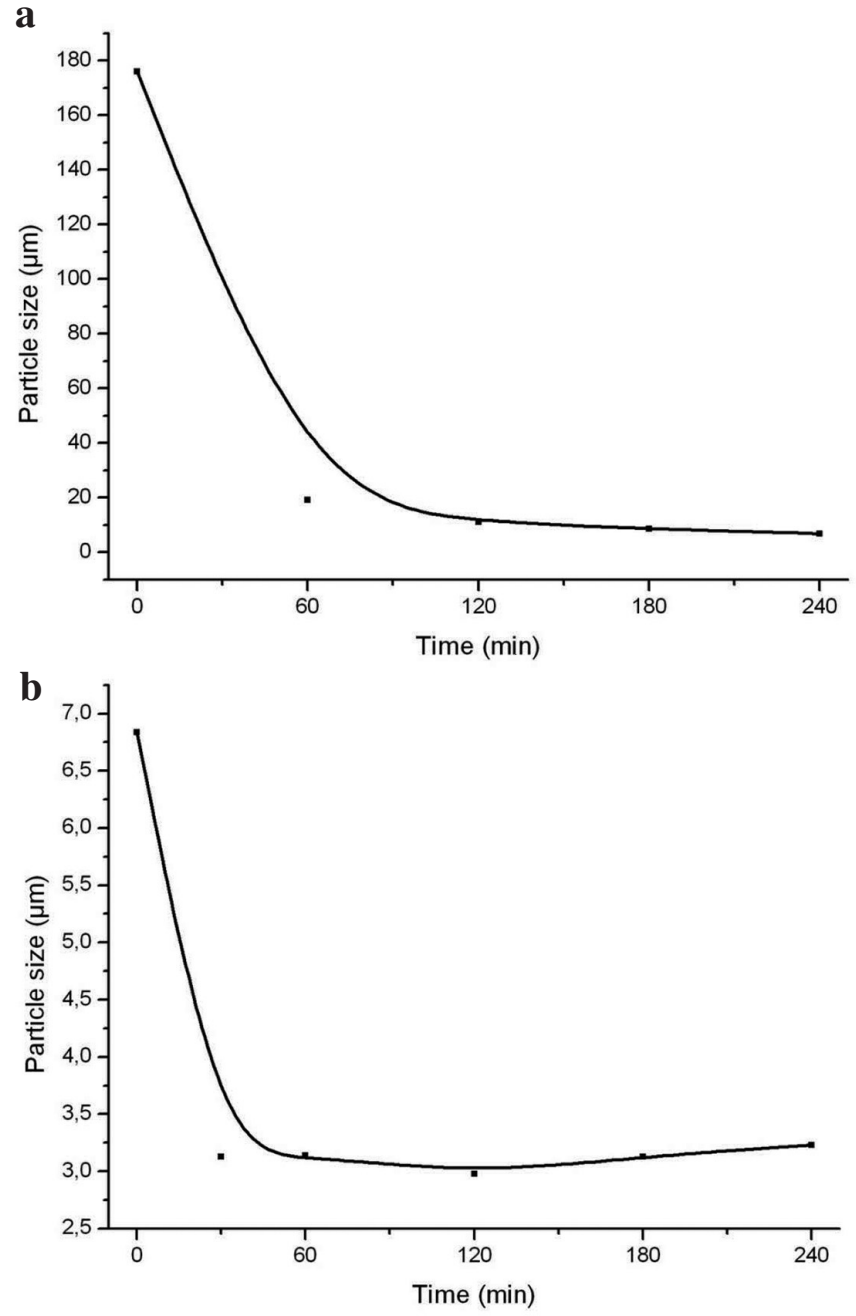

Fig. 2. Effect of grinding time on amber particle size; (a) the second grinding stage; (b) the third grinding stage.

Table 2

\section{SPINNORET}

\begin{tabular}{ll}
\hline Spin plate diameter & 80 \\
Number of capillaries per plate & 12 \\
Capillary diameter, mm & 0.35 \\
Capillary length, mm & 0.7 \\
Filter, mm & 0.062 \\
Steel sand, g & 100 \\
Steel sand corn size, $\mu \mathrm{m}$ & $350-500$
\end{tabular}

The amber particles obtained after grinding had irregular shape. The size of the particles after grinding stage (1) was about 200-500 $\mu \mathrm{m}$ (see Fig. 3a). Further grinding (3) significantly reduces particle size and also promotes smoothing of the surface of the particles to produce a more spherical shape (see Fig. 3b). Amber particles had a tendency to form large agglomerates consisting of smaller elementary particles (Fig. 3c).

In Figure 4, the "horizontal shoulder" in the interval $1160-1260 \mathrm{~cm}^{-1}$ is distinct and is the main characteristic feature of Baltic amber (Pakutinskiene et al., 2007). This 

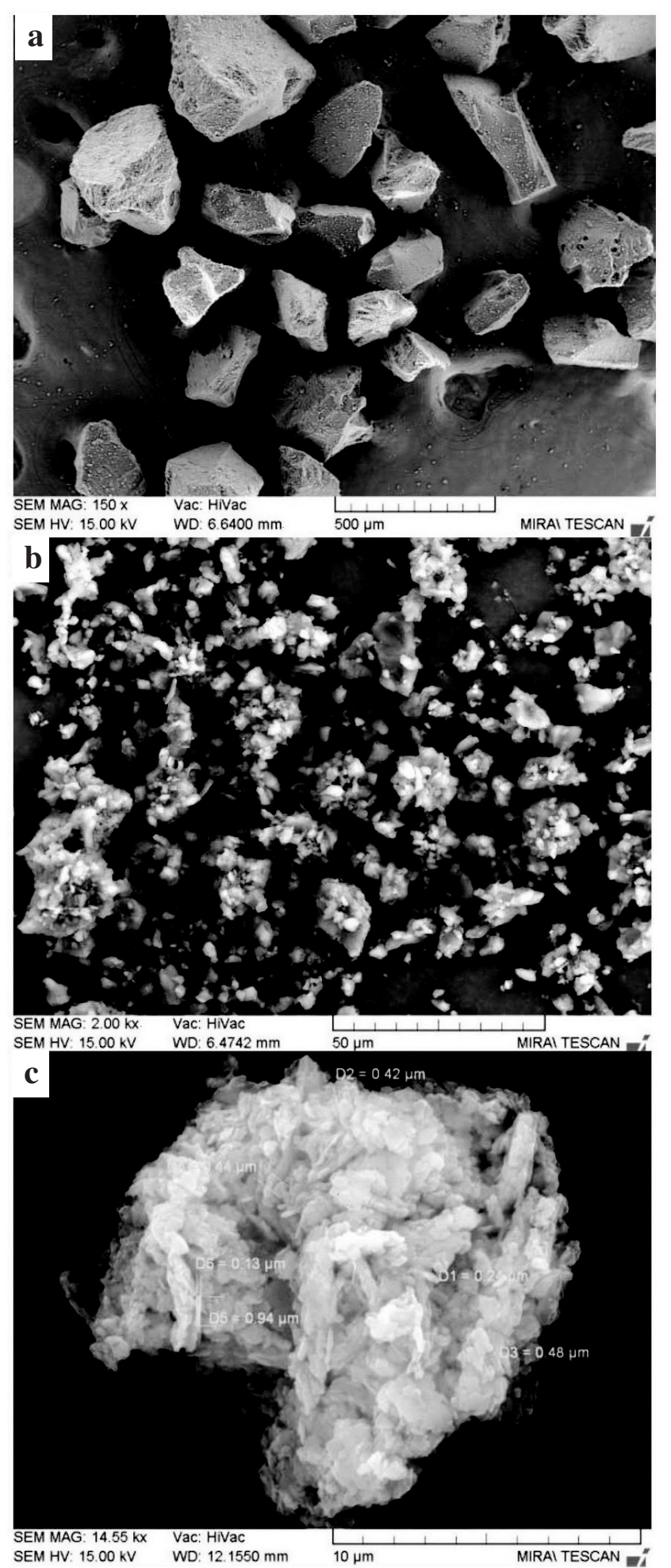

Fig. 3. Scanning electron microscope micrographs of amber particles; (a) particles after the first grinding stage, (b) particles after the third grinding stage, (c) amber particles agglomerate.

shoulder was also observed in the second spectrum in Figure $4 \mathrm{~b}$ the intense absorption band at $1158 \mathrm{~cm}^{-1}$ indicated the presence of $\mathrm{C}-\mathrm{O}$ bonds. Both spectra show a broad absorption band at $\sim 3400 \mathrm{~cm}^{-1}$, indicating -OH groups of alcohol and/or carboxylic acids, or absorbed water. A band indicating alkyl groups occurred between 2800 and 3000 $\mathrm{cm}^{-1}$. It is very typical for alkyl groups to have a band at $\sim 2926 \mathrm{~cm}^{-1}$ and two bands with similar intensity at $\sim 2867$ $\mathrm{cm}^{-1}$. The other two bands can also be due to alkyl groups: the first between $1420 \mathrm{~cm}^{-1}$ and $1460 \mathrm{~cm}^{-1}$, the second between 1375 and $1385 \mathrm{~cm}^{-1}$, which corresponds to $-\mathrm{CH}_{2}$ and $-\mathrm{CH}_{3}$ groups. Amber FTIR spectra absorption bands at 3040,1640 , and $887 \mathrm{~cm}^{-1}$ correspond to exocyclic methylene groups. The first, corresponding to an ethylene $\mathrm{C}-\mathrm{H}$ bond, the second to a $\mathrm{C}=\mathrm{C}$ double bond, and the third, also to the $\mathrm{C}-\mathrm{H}$ bond of ethylene. Exocyclic methylene groups are present in the various acid structures. The carbonyl region between $1695-1740 \mathrm{~cm}^{-1}$ is complex with significant overlap, which distorts the spectra and complicates the interpretation of it. However, the absorption band at 1738 $\mathrm{cm}^{-1}$ has good resolution, and there is an overlapping band at $\sim 1690 \mathrm{~cm}^{-1}$. The first band at $1738 \mathrm{~cm}^{-1}$, corresponds to a strong $\mathrm{C}=\mathrm{O}$ bond, such as in ketones, and the second band at $1690 \mathrm{~cm}^{-1}$ is more specific for carboxylic acid carbonyl groups. The strong ester band at $1738 \mathrm{~cm}^{-1}$ indicates the presence of esters, which always appears on spectra with an intensive absorption band at $1157 \mathrm{~cm}^{-1}$. Other FTIR spectrum bands of amber are much more difficult to interpret. In general, the chemical structure of amber was shown to remain unchanged, as all signals of the major functional groups of $-\mathrm{OH},-\mathrm{CH}_{2},-\mathrm{CH}_{3}, \mathrm{C}=\mathrm{C}$, and $-\mathrm{CO}-\mathrm{O}$ were retained.

The proposed two-stage extrusion processing was chosen for better dispersion of amber particles into the polymer matrix. Generally, the temperature of the extrusion equipment and, thus, the melt, are the major process parameters determining the viscosity and shearing of the polymer. For the extrusion stages the processing temperature was chosen such that the polymer viscosity was low enough to allow stable melt processing and dispersion of amber particles. For PA6, the ideal melt behaviour occurs at approximately 30-40 ${ }^{\circ} \mathrm{C}$ above the melting temperature (Ibanes et al., 2006). The extrusion temperature range was $235-255{ }^{\circ} \mathrm{C}$ for PA6. Extrusion time was 5 minutes. The extrusion compounding of PA6 with 5 and $1 \mathrm{wt} \%$ of amber did not present problems. At the employed processing temperatures amber particles become soft, and thus blended and were distributed homogeneously within the polymer matrix. Thermal calorimetric and gravimetric investigation showed that glass transition of the amber is at $155{ }^{\circ} \mathrm{C}$, and the destruction temperature is $454{ }^{\circ} \mathrm{C}$, which are high enough for utilized processing temperatures.

The PA6-amber filament was obtained using a standard melt spinning technology. The melt exited the extruder at pressure about $80-110$ bar and was transported through heated pipes to the spin pump. Up until spin pump, the process and throughput were pressure controlled depending on the lead pressure at the extruder head. From the spin pump on, the process was throughput-controlled. The polymer was pumped for filtration into the spin pack, which consisted of multiple metallic non-woven layers. After passing through all filtration stages, the melt flowed into the capillaries of the spinneret. The melt exited and formed a filament at the end of the capillary. A laminar air stream per- 


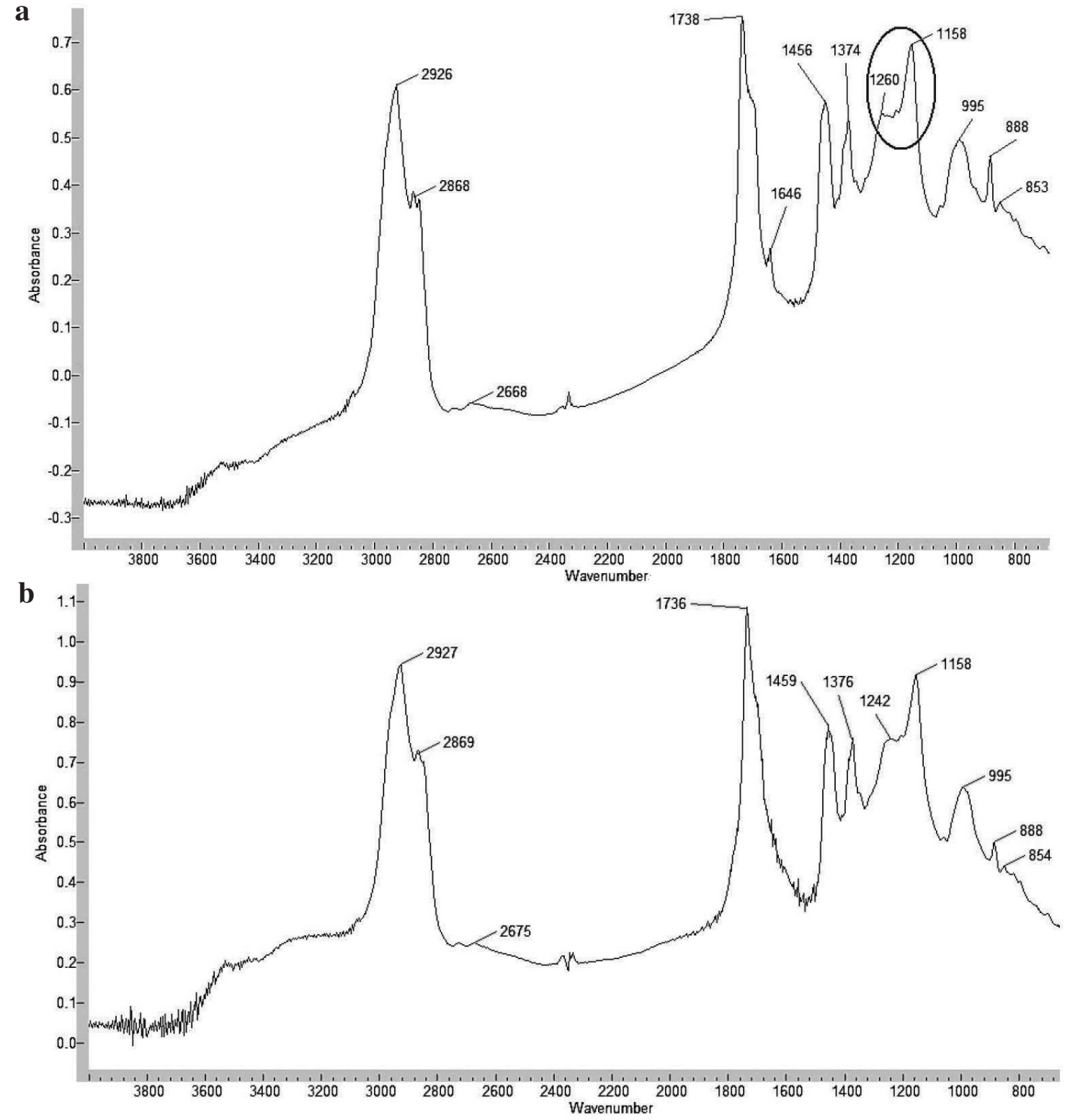

Fig. 4. Fourier transform infrared spectroscopy spectra of (a) initial amber and (b) amber particles after grinding.

Table 3

AMBER COMPOSITE FIBRES PROCESSING PARAMETERS FOR SPINNING TRIALS

\begin{tabular}{|c|c|c|c|c|c|c|c|c|c|c|c|c|c|c|c|}
\hline \multicolumn{3}{|c|}{ Trial } & \multicolumn{3}{|c|}{ Godet 1} & \multicolumn{3}{|c|}{ Duo 1} & \multicolumn{3}{|c|}{ Duo 2} & \multicolumn{3}{|c|}{ Godet 2} & \multirow{2}{*}{$\begin{array}{c}\text { Winder } \\
\mathrm{V}, \\
\mathrm{m} / \mathrm{min}\end{array}$} \\
\hline No. & $\begin{array}{c}\mathrm{n}_{\mathrm{s}} \\
\mathrm{rev}\end{array}$ & $\begin{array}{l}\mathrm{n}_{\mathrm{p}} \\
\text { rev }\end{array}$ & $\begin{array}{c}\mathrm{V}, \\
\mathrm{m} / \mathrm{min}\end{array}$ & $\begin{array}{l}\mathrm{T}, \\
{ }^{\circ} \mathrm{C}\end{array}$ & DR & $\begin{array}{c}\mathrm{V}, \\
\mathrm{m} / \mathrm{min}\end{array}$ & $\begin{array}{l}\mathrm{T}, \\
{ }^{\circ} \mathrm{C}\end{array}$ & DR & $\begin{array}{c}\mathrm{V}, \\
\mathrm{m} / \mathrm{min}\end{array}$ & $\begin{array}{l}\mathrm{T}, \\
{ }^{\circ} \mathrm{C}\end{array}$ & DR & $\begin{array}{c}\mathrm{V}, \\
\mathrm{m} / \mathrm{min}\end{array}$ & $\begin{array}{l}\mathrm{T}, \\
{ }^{\circ} \mathrm{C}\end{array}$ & DR & \\
\hline 0 & 12 & 32 & 1564 & 20 & 1.02 & 1596 & 20 & 1.85 & 2952 & 160 & 1.04 & 3070 & 23 & 0.98 & 3000 \\
\hline 1 & 16 & 32 & 1746 & 20 & 1.20 & 2095 & 80 & 1.40 & 2933 & 80 & 1.04 & 3050 & 23 & 0.98 & 3000 \\
\hline 2 & 18 & 14 & 2156 & 20 & 1.05 & 2273 & 20 & 1.05 & 2387 & 40 & 1.06 & 2530 & 23 & 0.99 & 2500 \\
\hline 3 & 18 & 14 & 2156 & 20 & 1.05 & 2273 & 20 & 1.05 & 2387 & 40 & 1.06 & 2530 & 23 & 0.99 & \\
\hline
\end{tabular}

$\mathrm{V}$, speed; $\mathrm{T}$, temperature; DR, drawing ratio

pendicular to the fibres axis cooled the extruded filaments directly below the spinnerets. We used the spinnerets with 12 capillaries per spin plate. Details on spinneret geometry and the filtering are listed in Table 2. The used spinneret gave good results with spin pressure, filtering and filament formation. The throughput of polymer melt was calculated for a 10 dtex per filament. The final filament count was 120 dtex at $2500 \mathrm{~m} / \mathrm{min}$. For one filament this result was about
$30 \mathrm{~g} / \mathrm{min}$. The used spinning line had two threads which gave a total extruder throughput of $3.6 \mathrm{~kg} / \mathrm{h}$.

After cooling, the amber composite fibres were lubricated using a spin finish to reduce friction in further processing. The processed spun fibres were drawn down vertically by one godet (Partial Oriented Yarn, POY) route and by two godets; the second godet revolved faster than the first one 
(Fully Drawn Yarn, FDY) (Penning, van Ruiten et al. 2003).

In the POY route, the process ran at 2500-3000 $\mathrm{m} / \mathrm{min}$ with no solid state drawing between godets and the only drawing of the filament occurred just below the spinnerets in the melt state of the material. This represented a take-up process of POY. The winding head wound the yarn ends onto paper tubes. Relaxation of the filaments on the bobbins was observed, which led to massive winding problems. Also, the filaments broke off below the spinneret holesin trials with winding speeds above $3500-4000 \mathrm{~m} / \mathrm{min}$. The amber particle agglomerates had probably disturbed the melt draw process. Therefore, the winding process was further modified.

We attempted to use solid-state drawing in order to reduce the observed relaxation in the POY route for amber filament. For this, the filament was wound in the FDY process. The winding speed was $2500 \mathrm{~m} / \mathrm{min}$, but the take up speed of the first godet was reduced and the filament was led over the secondary godet pairs to draw the fibres at above room temperature. The solid-state draw temperature occurred above the glass transition temperature of the polymer. The draw ratios (DR) were varied between factors 1.9 and 1.0.

The primary PA6 melt spinning trial (0) was used as reference. The first trial (1) of amber filaments was unsuccessful. The filaments breached off as the drawing stage occurred. The total drawing ratio (TDR) was about 1.72. A more stable spinning was obtained for the second (2) and the third (3) trials in which the TDR was decreased to 1.15 . The average throughput was about 170 dtex or 15 dtex per filament. Parameter $n_{s}$ indicated the number of revolutions per minute of the spinning pump; $\mathrm{n}_{\mathrm{p}}$ - the number of revolutions per minute of the spin-finish pump. The spinning pump forwarded the melt towards the spinneret. The spinfinish pump covered the filament ends with spin-finish after spinning. For trials (2) and (3), the revolution values were 18 and 14, correspondingly. Godet 1, together with an idler roll, took over the filament ends directly after spinning. The speed of this Godet 1 was experimentally chosen to be nearly the same as the speed of the filament ends after the spinneret. It was considered, that GodetDuo 1 was "heavily" drawing the yarn ends (drawing ratio DR $=1.05-1.40$ ), but GodetDuo 2 was additionally slightly drawing the yarn ends $(\mathrm{DR}=1.04-1.06)$. The drawing ratio was adjusted with the godets and duogodets speed was $\mathrm{V}=1746-3050$ $\mathrm{m} / \mathrm{min}$. Godet 2 was relaxing the filament ends at room temperature $(\mathrm{DR}=0.98-0.99)$. The godets were operating with different temperatures in the range $20-160{ }^{\circ} \mathrm{C}$.

\section{CONCLUSIONS}

Amber particle preparation technology is required for amber composite fibre manufacturing. The presented technology allows processing of amber particles with mean size up to $3 \mu \mathrm{m}$. In addition, SEM showed that the obtained particles were agglomerates of elementary amber particles and had regular shape. FTIR data showed that the proposed grinding process does not affect amber particle chemical composition and the characteristic absorption bands of corresponding functional groups.

The melt spinning manufacture of polyamide-amber composite fibre was examined. Melt spinning and the FDY and POY winding of the fibre was accomplished.

\section{ACKNOWLEDGMENTS}

This research was funded in the frame of a Eureka/MNT ERA-Net European consortium, Project "Fundamental and Industrial Fossilized Resin Research for the Production of Composite Material” Nr. E!5798.

\section{REFERENCES}

Agarwal, L., Isar, J., Meghwanshi, G. K., Saxena, R. K. (2007). Influence of environmental and nutritional factors on succinic acid production and enzymes of reverse tricarboxylic acid cycle from Enterococcus flavescens. Enzym. Microb. Tech., 40 (4), 629-636.

Archambault, J. C., Bonte, F., Cauchard, J. H. (2008). FR. Patent No. 2911779.

Barletta, E., Wandelt, K. (2011). High resolution UHV-AFM surface analysis on polymeric materials: Baltic Amber. J. Non-Cryst. Solids, 357 (5), 1473-1478.

Beck, C. W., Wilbur, E., Meret, S. (1964). Infra-red spectra and the origin of amber. Nature, 201 (4916), 256-257.

Brody, R. H., Edwards, H. G. M. (2001). A study of amber and copal samples using FT-Raman spectroscopy. Spectrochim. Acta, Part A, 57, 1325-1338.

Chen, S. W., Xin, Q., Kong, W. X., Min, L., Li, J. (2003). Anxiolytic-like effect of succinic acid in mice. Life Sci., 73 (25), 3257-3264.

Dastjerdi, R., Montazer, M. (2010). A review on the application of inorganic nano-structured materials in the modification of textiles: Focus on anti-microbial properties. Colloids Surf. B Biointerfaces, 79 (1), 5-18.

Dunlop, J. A. (2006). Baltic amber harvestman types (Arachnida: Opiliones: Eupnoi and Dyspnoi). Fossil Record-Mitteilungen aus dem Museum für Naturkunde, 9 (2), 167-182.

Fasahat, F., Dastjerdi, R., Mojtahedi, M. R. M., Hoseini, P. (2015). Wear properties of high speed spun multi-component PA6 nanocomposite fabrics; abrasion resistance mechanism of nanocomposites. Wear, 322, $117-125$.

Grimalt, J. O., Simoneit, B. R. T., Hatcher, P. G., Nissenbaum, A. (1988). The molecular composition of ambers. Org. Geochem., 13 (4), 677-690.

Hazelwood, T. L. (2001). Can't Live Without it: The Story Haemoglobin in Sickness and in Health. Nova Science Publishing Inc, New York. 226 pp.

Ibanes, C., David, L., De Boissieu, M., Séguéla, R., Epicier, T., Robert, G. (2004). Structure and mechanical behavior of nylon-6 fibres filled with organic and mineral nanoparticles. I. Microstructure of spun and drawn fibres. J. Polym. Sci., Part B: Polym. Phys., 42 (21), 3876-3892.

Ibanes, C., Boissieu, M. de, David, L., Seguela, R. (2006). High temperature behaviour of the crystalline phases in unfilled and clay-filled nylon 6 fibres. Polymer, 47 (14), 5071-5079.

Lambert, J. B., Frye, J. S. (1982). Carbon functionalities in amber. Science, 217 (4554), 55-57.

L,ašenko, I. (2014). Dzintara cel̦š - Latvijas nākotne pasaulē [Lyashenko, I. Amber Way: Towards the Future of Latvia in the World]. MantoPrint, Riga. 225 pp. (in Latvian).

Sprudza, D., Lasenko, I., Roga, S., Meirena, V., Bozileva, E. (2009). Assessment of harmlessness of modified amber powder tissues serviette. In: Rīgas 
Stradina Universitātes Zinātniskie Raksti. 7. sēj. [Research Papers of Rīga Stradiṇš University. Vol. 7], Rīga, pp. 70-78.

Synoradzki, L., Arct, J., Safarzynski, S., Hajmowicz, H., Sobiecka, A., Dankowska, E. (2012). Characteristics and application of Baltic amber in pharmaceutical and cosmetic industries. Przemysl Chemiczny, 91 (1), 89-94.

Matuszewska, A., John, A. (2004). Some possibilities of thin layer chromatographic analysis of the molecular phase of Baltic amber and other natural resins. Acta Chromatogr., 14, 82-91.

Mie, Y., Kishita, M., Nishiyama, K., Taniguchi, I. (2008). Interfacial electron transfer kinetics of myoglobins chemically modified with succinic anhydride at an indium oxide electrode. J. Electroanal. Chem., 624 (1-2), 305-309.

Mills, J. S., White, R., Gough, L. J. (1984). The chemical composition of Baltic amber. Chem. Geol., 47 (1-2), 15-39.

Pakutinskiene, I., Kiuberis, J., Bezdicka, P., Senvaitiene, J., Kareiva, A. (2007). Analytical characterization of Baltic amber by FTIR, XRD and SEM. Canad. J. Anal. Sci. Spectroscopy, 52 (5), 287-294.

Pastorelli, G. (2011). A comparative study by infrared spectroscopy and optical oxygen sensing to identify and quantify oxidation of Baltic amber in different ageing conditions. J. Cult. Herit, 12 (2), 164-168.

Pastorelli, G., Richter, J., Shashoua, Y. (2011). Photoageing of Baltic amber: Influence of daylight radiation behind window glass on surface colour and chemistry. Polym. Degrad. Stab., 96 (11), 1996-2001.

Pastorelli, G., Shashoua, Y., Richter, J. (2013). Hydrolysis of Baltic amber during thermal ageing — an infrared spectroscopic approach. Spectrochim. Acta A Mol. Biomol. Spectrosc., 106, 124-128.

Pastorelli, G., Shashoua, Y., Richter, J. (2013). Surface yellowing and fragmentation as warning signs of depolymerisation in Baltic amber. Polym. Degrad. Stab., 98 (11), 2317-2322.
Penning, J. P., Ruiten, J. van, Brouwer, R., Gabrièlse, W. (2003). Orientation and structure development in melt-spun Nylon-6 fibres. Polymer, 44 (19), 5869-5876.

Ragazzi, E., Roghi, G., Giaretta, A., Gianolla, P. (2003). Classification of amber based on thermal analysis. Thermochimica Acta, 404 (1-2), 43-54.

Schäfer, K. (1999). Melt spinning: technology. In: Karger-Kocsis, J. Polypropylene. Springer, Netherlands, pp. 440-445.

Synoradzki, L., Arct, J., Safarzynski, S., Hajmowicz, H., Sobiecka, A., Dankowska, E. (2012). Characteristics and application of Baltic amber in pharmaceutical and cosmetic industries. Przemysl Chemiczny, 91 (1), 89-94.

Thrall, M. A., Baker, D. C., Lassen, E. D. (2004). Veterinary Hematology and Clinical Chemistry. Lippincot Williams \& Wilkins, Philadelphia. 618 pp.

Tonidandel, L., Ragazzi, E., Traldi, P. (2009). Mass spectrometry in the characterization of ambers. II. Free succinic acid in fossil resins of different origin. Rapid Commun. Mass Spectrom., 23 (3), 403-408.

Utracki, L. A. (2006). Fibres from polymeric nanocomposites. Indian J. Fibre Text. Res., 31 (1), 15-28.

Valeria, M. (1968). The analysis of archeological amber and amber from the Baltic Sea by thin-layer chromatography. J. Chromatogr. A, 33, 24-28.

Valeria, M., Roberto, S. (1985). Correlations between Baltic amber and Pinus resins. Phytochem., 24, 12-17.

Yamamoto, S., Otto, A., Krumbiegel, G., Simoneit, B. R. T. (2006). The natural product biomarkers in succinite, glessite and stantienite ambers from Bitterfeld, Germany. Rev. Palaeobot. Palynol., 140 (1-2), 27-49.

Zhao, J., Ragazzi, E., McKenna, G. B. (2013). Something about amber: Fictive temperature and glass transition temperature of extremely old glasses from copal to Triassic amber. Polymer, 54 (26), 7041-7047.

Received 7 March 2016

\section{DZINTARA DAḶIN̦U, KURAS DERĪGAS KOMPOZĪTA ŠĶIEDRAS KAUSĒJUMU VĒRPŠANAI, IEGŪŠANA}

Tika izveidota poliamīda šḳiedra ar integrētām dzintara daḷin̄ām. Dzintara dalinas tika iegūtas, smalcinot dzintaru planetārās smalkmalšanas dzirnavās. Lai novērtētu sagatavoto dzintara daḷiņu struktūru un to lielumu, tika izmantota skenējošā elektronu mikroskopija un granulometriskā testēšana. Furjē infrasarkanā spektroskopija tika izmantota, lai analizētu dzintara dạ̣iņu kịmisko struktūru. Secināts, ka dzintara daḷiṇu vidējais izmērs ir līdz $3 \mu \mathrm{m}$. Dzintara kīmiskais sastāvs pirms un pēc smalcināšanas palika nemainīgs. Dzintara daḷiṇas tika sakausētas un ekstrudētas, kā matricu izmantojot poliamīdu 6. Apstrādē tika izmantota kausējuma vērpšana, lai izgatavotu poliamīda dzintara pavedienus. Daḷeji gatavā dzija un pilnībā izstrādātā dzija tika iegūtas tikai pēc hot-drawing eksperimentiem. Dzintara kompozīta škiedru pētījumu rezultāti var būt nozīmīgi tekstilizstrādājumu ražošanā. 